ラット肝再生に拉けるエストロゲンの役割についての研究

小東 克次

瀬古 修二
福田

井村

善弘 姫野 泰雄

裕夫"

劇症肝炎ならびに訮硬変症における機能不全におい て，その代償作用としての肝再生は生死にかかわる重 要な問題であり,従来より肝再生を促進するホルチン， 増殖因子の研究がすすめられている，近年ラットい ヒト ${ }^{2)}$ 肝にもエストロゲン（E）に対する特異的なりセ プター (ER) が存在し, 肝も $\mathrm{E}$ の標的臓器となりうる ことが報告されている。しかしながら肝再生に拉ける Eゃ ERについて検討した報告3,4)少ない，今回我々 は訮再生に括けるEの役割を検討するため，雄ラット で肝部分切除 $(\mathrm{PH})$ 後の肝再生過程における, 血清エ ストラジオール $\left(\mathrm{E}_{2}\right)$ 濃度, 肝細胞質 ER, DNA 合成 の変化を認べだ。さらに $\mathrm{PH}$ 時に $\mathrm{E}_{2}$ を投与し， $\mathrm{ER}$ ， DNA 合成, 肝重量に及ぼす影響についても検討し，若 干の知見を得たので報告する。

方法：雄 Sprague-Dawley ラット（体重250g）を用 い,ゴマ油に溶解した $\mathrm{E}_{2} 5 \mathrm{mg}$ 皮下投与 ( $\mathrm{E}_{2}$ 群)，70\% 肝部分切除 $\left(\mathrm{PH}\right.$ 群), 拉よび $\mathrm{PH}$ 直後に $\mathrm{E}_{2}$ 投与 $(\mathrm{PH}+$ $\mathrm{E}_{2}$ 群)の 3 群を作った。経時的に採取した血清につい て $\mathrm{E}_{2}$ 濃度を RIA (エストラジオール・I-125・キット) により，肝組織について ER を既報ら)のごとく EIA ( ボット ER-EIA モノクローナルキット)により湘定し た。また $\left[{ }^{3} \mathrm{H}\right]$ thymidine $5 \mu \mathrm{Ci}$ を腹腔内投与後 1 時間 後に採取した肝よりDNAを抽出し，そのDNA 量括 よび放射活性を測定し，肝 DNA 合成の指標とした。な お各時間毎に 2ー5匹のラットを用い, Student's $t$ testにより統計処理を行った。

結果：PH 後血清 $\mathrm{E}_{2}$ 濃度は上昇し， 3 時間後に191 $\mathrm{pg} / \mathrm{m} l$ となり，その後下降し24時間後にはほぼ前值に まで低下した(Fig. A).一方 $\mathrm{E}_{2}$ 投与では 1 時間後より $30,000 \mathrm{pg} / \mathrm{m} l$ 以上となり, 24 時間後です高値が持続し た.

肝細胞質 ER は 3 群共に低下がみられ，特に PH 群 では血清 $\mathrm{E}_{2}$ 濃度の最高時に一致して最低の $\mathrm{ER}$ 值と なった。しかしいずれの群です ERの低下は一過性で

*京都大学第 2 内科

＜受付日61年12月10日 >
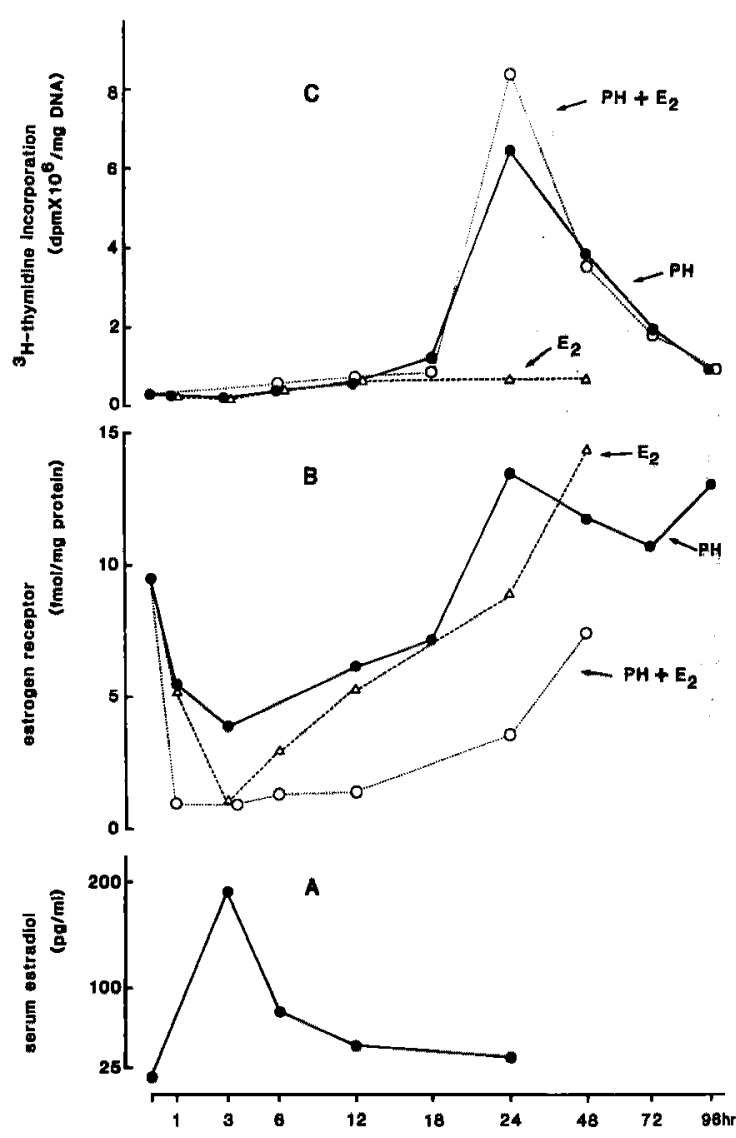

Fig. Serum estradiol (A), cytosolic estrogen receptor (B) and DNA synthesis (C) in rat livers at different hours after $\mathrm{PH}$.

あり, PH 群は24時間後には前值のレペルに回復した， 3 群の中で $\mathrm{PH}+\mathrm{E}_{2}$ 群では，ERはすでに 1 時間後に は最低となり，その後む比較的長時間低值が持続する 傾向がみられた（Fig. B).

肝 DNA 合成は Fig. Cのよ5に PH 18時間後より 上昇が始まり，24時間後をピークとして96時間後まで 続いた、 $\mathrm{PH}+\mathrm{E}_{2}$ 群では $\mathrm{PH}$ 群に比してDNA 合成が 若干高まる傾向が得られたが，有意差なく，肝重量さ らには 1 週間後に判定した肝再生率〔(屠殺時肝重量一 PH 時肝重量)/PHで切除した肝重量】についても有 
意な差はみられなかった。一方 $\mathrm{E}_{2}$ 群では DNA 合成の 上界はみられなかった。

考察：近年男女を問わず肝す ER を持ち，Eに反応 する臟器の1つであることが明らかにされている。現 在までにE投与により肝の plasma renin substrate, 凝固因子，リポ蛋白等の合成が高まることが知られて おうり，その作用機序としては ERが核で DNA と結合 し，遺伝情報の発現，蛋白質誘導に㗢くものと考光ら れている. Eが肝再生過程でどのような役割を果して いるのかを検討した報告3.4) は少ない，今回の我々の検 討です Francavilla $5^{3)}$, Fisher $5^{4)}$ 同様, PH 後一 過性に細胞質 ERの低下かみられた。彼らは細胞質 ERの低下と共に，核分画 ERの上界を明らかにし， ERの核への translocation と解する成績を報告して いる。一般的に生理的な血中 $\mathrm{E} の$ 変化では肝細胞質 $\mathrm{ER}$ の変動はない(ف゙が，大量のEを投与すると ER の核 への translocation がおこる゙ことが知られており，今 回の $\mathrm{E}_{2}$ 群での細胞質 $\mathrm{ER}$ の低下はこれによるすのと 考えられる、PH 後に translocationの扣こる機序は不 明であるが，大量のEを投与した時と同様の変化がみ られることから，それと似た状況が扢こっているもの 之推察される. 事実我々の検討では $\mathrm{PH}$ 後残存肝の $\mathrm{E}$ を代謝する能力の低下によると思われるが, 血清 $\mathrm{E}_{2}$ 濃 度は急上昇し，時間的に一致して細胞質 ER は逆に低 下するといら結果が得られた。しかしながら彼らの報 告では肝細胞質 ER の低下は12 18時間後から始ま り，24，48時間後も低值を示しており，我々の今回の 成績とは異なる。これは用いたラットの性差による可

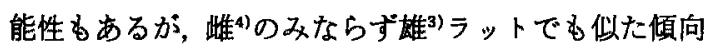
であり，むしろ ER の測定方法によるのかるしれない． すなわち彼らの成績は binding assayを用いたのに対 し, 我々は unoccupied formのみならず, occupied form の ER む湘定しうるEIA を用いたことによる差 かもしれない。

最後に外因性 $\mathrm{E}_{2}$ の肝再生に及ぼす効果であるが，
Fisher ら"は集ラットで PH 後 $\mathrm{E}_{2}$ 投与により肝 DNA 合成や肝再生率を高めた成績を報告しているが，我々 の検討ではそのような成續は得られず， $\mathrm{E}_{2}$ の効果は明 らかでなかった。これは我及が用いた雄ラット肝に扰 いてはERが量的に少ないこと帛や male specific estrogen binder ${ }^{9)}$ 存在することによるるのと思われ ろ.

しかしながら PH 後 DNA 合成の始をるよりもかな り早い時期に, ERの translocationがおこることは， それによりいかなる遺伝情報が発現されるかは現時点 では不明であるが，肝再生過程で ER を介する機序が 何らかの役割を演じている可能性が示焧され，今後の 研究課題と考学られる。

本論文の要旨は, 第21回日本肝臟学会䌊会(米子市) 飞批 いて発表した。

本研究の一部は文部省科学研究費 (一般研究 C. No. 61570337）によった。

卖引用語：肝再生，エストロゲン，エストロゲンリ セプター

\section{文献}

1) Chamness GC, Costlow ME, McGuire WL: Steroids $26: 363,1975$

2) Duffy MJ, Duffy GJ: J Steroid Biochem 9: 233, 1978

3) Francavilla A, Di Leo A, Eagon PK, et al: Gastroenterology $86: 552,1984$

4) Fisher B, Gunduz N, Elizabeth A, et al: Cancer Res $44: 2410,1984$

5）小東克次, 福田善弘, 井村裕夫, 他：肝䁍 27 ： 1444,1986

6) Marr W, White JO, Elder MG, et al : Biochem J $190: 17,1980$

7) Aten RF, Weinberger $\mathrm{MJ}$, Eisenfeld $\mathrm{AJ}$ : Endocrinology $102: 433,1978$

8) Rochman H, Rosner B, Mathey B, et al: J Endocr 106: 95, 1985

9) Eagon PK, Fisher SE, Imhoff AF, et al : Arch Biochem Biophys 201 : 486, 1980

\title{
Study on the role of estrogen in rat liver regeneration
}

\author{
Katsuji Kohigashr, Yoshihiro Fukuda, Yasuo HImeno, \\ Shuji SEKo and Hiroo IMURA*
}

\footnotetext{
* Second Department of Internal Medicine, School of Medicine, Kyoto University (Kyoto)
} 